\title{
Protective Effect of Tribulus terrestris Hydroalcoholic Extract Against Cisplatin-Induced Apoptosis on Testis in Mice
}

\author{
Efecto Protector del Extracto Hidroalcohólico de Tribulus terrestris contra \\ la Apoptosis Inducida por Cisplatino sobre los Testículos en Ratones
}

\author{
Zahra Keshtmand"; Ali Ghanbari**; Mozafar Khazaei** \& Arezou Rabzia**
}

KESHTMAND, Z.; GHANBARI, A.; KHAZAEI, M. \& RABZIA, A. Protective effect of Tribulus terrestris hydroalcoholic extract against cisplatin-induced apoptosis on testis in mice. Int. J. Morphol., 33(1):279-284, 2015.

SUMMARY: Cisplatin is an anti-cancer drug used in chemotherapy. One of the limiting side effects of cisplatin is decreasing genital gland function, azoospermia and oligospermia. Tribulus terrestris (TT) has been used as an aphrodisiac. The present study amid to investigate protective effect of TT hydroalcoholic extract against cisplatin-induced apoptosis on testis in mice. Male adult mice ( $\mathrm{n}=30)$ were divided into control and 4 experimental groups $(\mathrm{n}=6)$. Control group received saline, first experimental group received cisplatin $(5.5 \mathrm{mg} / \mathrm{kg}) \mathrm{and}$ other three experimental group received cisplatin $(5.5 \mathrm{mg} / \mathrm{kg})$ and different doses of hydroalcoholic extact of TT (100, $300 \mathrm{and} 500 \mathrm{mg} / \mathrm{kg} / \mathrm{i} . \mathrm{p})$ respectively. Day after the last injection, histopathology and histomorphic analysis and also TUNEL assay on mice testis were performed. Weights of body and testis, seminiferous tubules diameter and apoptotic index were assessed. Data analysis was performed using one-way ANOVA followed by Tukeys' test. The results showed that cisplatin lead to a reduction in the weight of body and testes, and significantly increased apoptotic index compared to the control group $(\mathrm{P}<0.001)$, while in treated groups with TT, the weights of body and testis and seminiferous tubules diameter were significantly higher compared with cisplatin group $(\mathrm{P}<0.001)$, but apoptotic index did not show significant differences. The study demonstrates that extract of TT could protective effect of on cisplatin-induced apoptosis of testis and seminiferous tubules diameter that may be related to the presence of antioxidant components acting via a multitude of central and peripheral mechanisms

KEY WORDS: Cisplatin; Tribulus terrestris; Apoptosis; TUNEL.

\section{INTRODUCTION}

Cis-Diamminedichloroplatinum (II) (cisplatin) is one of the most effective anticancer agents for the treatment of patients with a wide spectrum of tumors. However, the use of a high dose of cisplatin is difficult in practice predominantly because of its strong side effects occurring in the reproductive tracts (Frezza et al., 2010).

Cisplatin toxicity is occurred by increased production of reactive oxygen species (ROS) and decreased production of antioxidants (Chirino \& Pedraza-Chaverri, 2009). The formation of ROS depends on the concentration of CDDP and the duration of exposure. ROS might reduce the capacities of the cell by DNA damage (Brozovic et al., 2010).

Tribulus terrestris (TT) herb has been commonly used in folk medicine to energize, vitalize and improve sexual function and physical performance in men. Although different effects of TT on animals and men have been evaluated and many active compounds from TT extract have been established (the mode of its action and efficacy remains uncertain and controversial. It is widely believed that TT affects strongly the androgen metabolism increasing significantly testosterone or testosterone precursor levels (Gauthaman \& Ganesan, 2008).

Studies show that TT contains steroids, saponins, flavonoids, alkaloids, unsaturated fatty acids, vitamins, tannins, resins, nitrate potassium, aspartic acid and glutamic acid (Karimi et al., 2012). This plant has several advantages including antimicrobial, antibacterial, antioxidant and antitoxic activities used in the treatment of cardiovascular diseases, diabetes, tumors, articular pains and respiratory diseases (Abbas et al., 2010).

The aim of the current study is to investigate the influence of TT extract on histological characteristics of testis were evaluated. TUNEL assay was also performed for showing the occurrence of apoptosis in the testis.

\footnotetext{
* Department of Biology, Science and Research Branch, Islamic Azad University, Tehran, Iran.

*** Fertility and Infertility Research Center, Kermanshah University of Medical Sciences, Kermanshah, Iran.
} 


\section{MATERIAL AND METHOD}

Preparation of plant extract. T. terrestris was purchased from a traditional medicine center and identified and authenticated by a botanist. TT ( $400 \mathrm{~g})$ were powdered and added to $800 \mathrm{cc}$ of $70 \%$ ethanol and were left to macerate at room temperature for 4 hours. Then, the soaked seeds were extracted by percolation method and the obtained extract was concentrated in the vacuum and was dried in the flat surface (Khazaei \& Salehi, 2006). The weight of the obtained extract was $6.5 \mathrm{~g}$. The extract was dissolved in distilled water and was immediately administered intraperitoneally (IP) to mice, expressed as mg of extract per kg of body weight and injection administered from day one for 4 days.

Drug. Cisplatin (EBEWE Pharma, Unterach, Austria) was dissolved in saline in darkness, $10-15 \mathrm{~min}$ before use and an intraperitoneal injection $(5.5 \mathrm{mg} / \mathrm{kg})$ was given at the one day of experiment (Bagnis et al., 2001).

Animals-inberd. Thirty male Balb/c mice with weight of $25-30 \mathrm{~g}$ were used. Animals were kept in the temperature of $22 \pm 2{ }^{\circ} \mathrm{C}$, under controlled environmental conditions, 12 hour light-dark cycles and fed standard pellet chow and water ad libitum. All experiments procedures were conducted in accord with the principles for the care and use of laboratory animals in research and approved by local ethics committee of our university.

Experiment protocol. After a quarantine period of 7 days, 30 mice were randomly divided into five groups $(n=6)$. Group I was used as control and received saline intraperitoneally (i.p). Group II received only cisplatin in single dose of $5.5 \mathrm{mg} / \mathrm{kg} /$ i.p. daily. Group III received cisplatin $+100 \mathrm{mg} / \mathrm{kg}$ extract of TT. Group IV received cisplatin $+300 \mathrm{mg} / \mathrm{kg}$ extract of TT. Group V received cisplatin $+500 \mathrm{mg} / \mathrm{kg}$ extract of TT. Groups experimental were treated over period of 4 consecutive days.

After 4 days, pubertal mice of five groups were weighed and were anesthetized with ethylether and killed by decapitation. The testes were removed and weighed. Then, $5 \mathrm{~mm}$ histological sections were achieved from paraffin blocks of left testes. The sections stained with Hematoxilin and Eosin and also with terminal deoxynucleotidyl transferase (TdT)-mediated deoxy-UTP nick end labeling (TUNEL) as previously described (Chehreie et al., 2011).

Morphometry. For this purpose we measured the external diameter and the lumen diameter of 150 seminiferous tubules per animal by fitting a graticule of a calibrated linear scale in the $\times 10$ eyepiece of Leitz microscope at objective lens $\times 40$ using of calibrated Motic software. For measuring the tubular diameter was subtracted from luminar diameter (Orazizadeh et al., 2010).

TUNEL Assay. Apoptosis was assessed by terminal deoxynucleotidyl transferase (TdT)- mediated deoxy-UTP nick end labeling (TUNEL) assay by using In Situ Cell Death Detection Kit, AP (RocheDiagnostics Deutschland GmbH, Germany; 16848091).

The paraffin sections were dewaxed and rehydrated by standard methods. Proteases were added and incubated with $5 \%$ of appropriate normal serum for $30 \mathrm{~min}$ at $37^{\circ} \mathrm{C}$. The slides were washed in phosphate buffered saline (PBS). The sections were permeabilized ( $2 \mathrm{~min}$, on ice) and incubated with TUNEL reaction mixture $\left(60 \mathrm{~min}, 37^{\circ} \mathrm{C}\right)$. Anti-fluorescein-AP was added and incubated ( $30 \mathrm{~min}, 37$ $\left.{ }^{\circ} \mathrm{C}\right)$. Contra staining was undertaken with propidium Iodide (PI; $1 \mu \mathrm{g} / \mathrm{ml}-1$ ). Apoptotic index (AI) was calculated by dividing the number of TUNEL-positive cells to total number of the cells in randomly focused fields, and the result was multiplied by 100 (Lirdi et al., 2008).

Statistical analysis. Values are expressed as mean \pm SD. Statistical analysis was performed by unpaired Student's $t$ test and significance was put at $\mathrm{P}<0.05$.

\section{RESULTS}

The mean of weights of body and testis had significantly decreased in E1 in comparison with control group $(P=0.037)$ but in-group that received cisplatin $+300 \mathrm{mg} / \mathrm{kg}$ extract of TT increased significantly in comparison with cisplatin group ( $\mathrm{P}=0.01)$ (Figs 1A and 1B). Testicular sections showed that the diameter of the seminiferous tubules were reduced in cisplatin treated mice $(\mathrm{P}=0.001)$ and seminiferous tubules diameter increased significantly $(\mathrm{P}=0.001)$ in group that received cisplatin $+300 \mathrm{mg} / \mathrm{kg}$ extract of TT group in comparison with cisplatin group (Figs. 1C and 2).

TUNEL staining sections of the testes showed that both germ cells and sustentocytes can be induced to apoptosis (Fig. 3) and evaluated apoptotic index of these sections presented significant increase in cisplatin group in comparison with control group ( $\mathrm{P}=0.001)$ (Figs. 1D and 3). 
$\mathbf{A}$

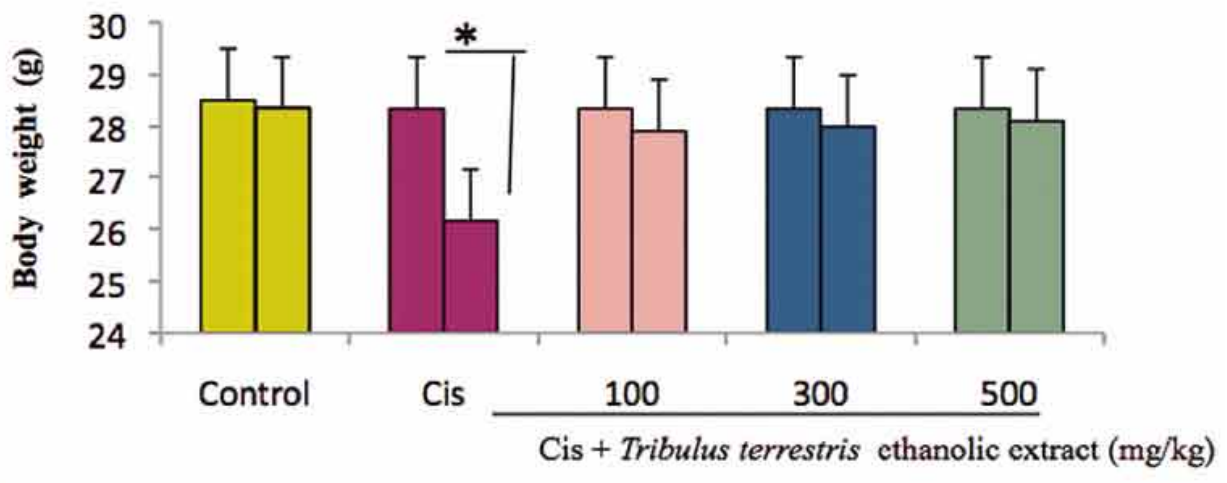

B

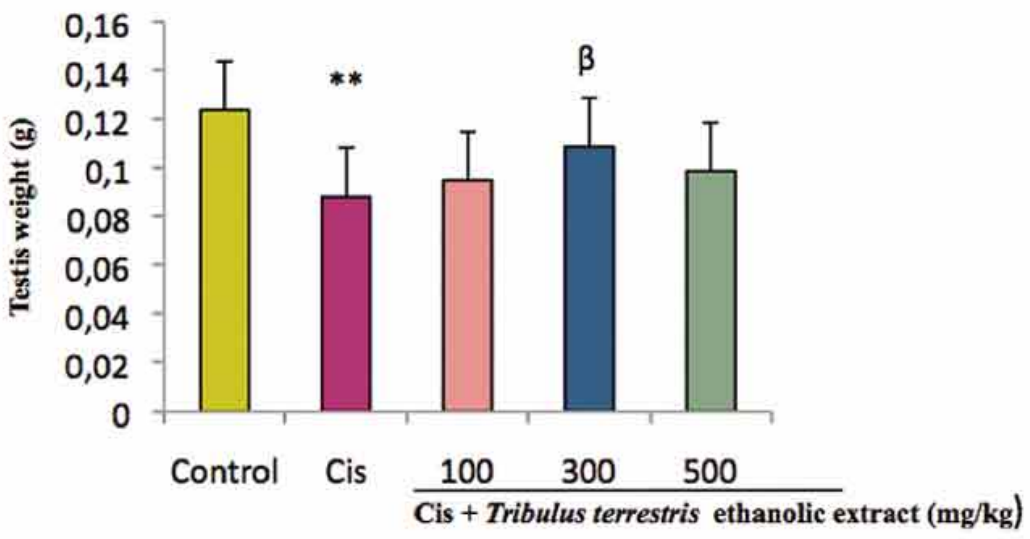

C

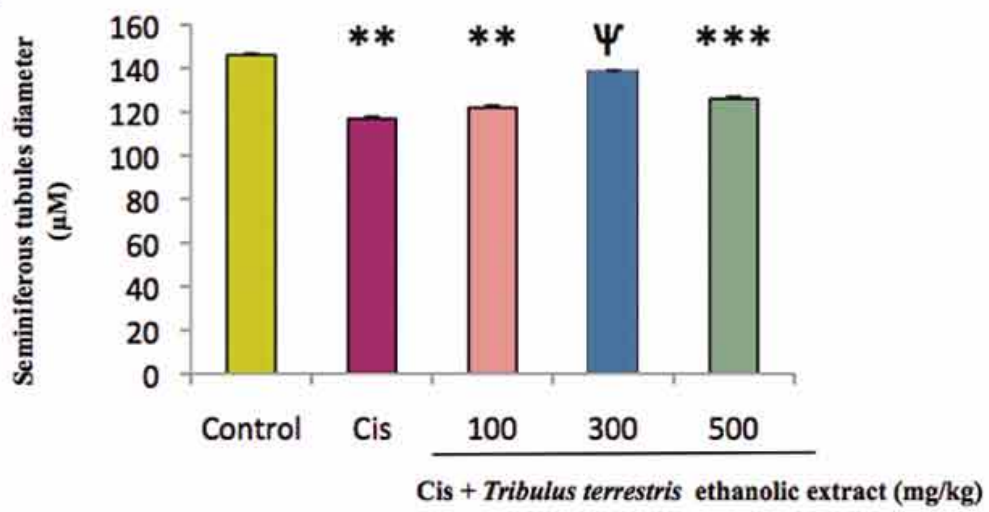

D

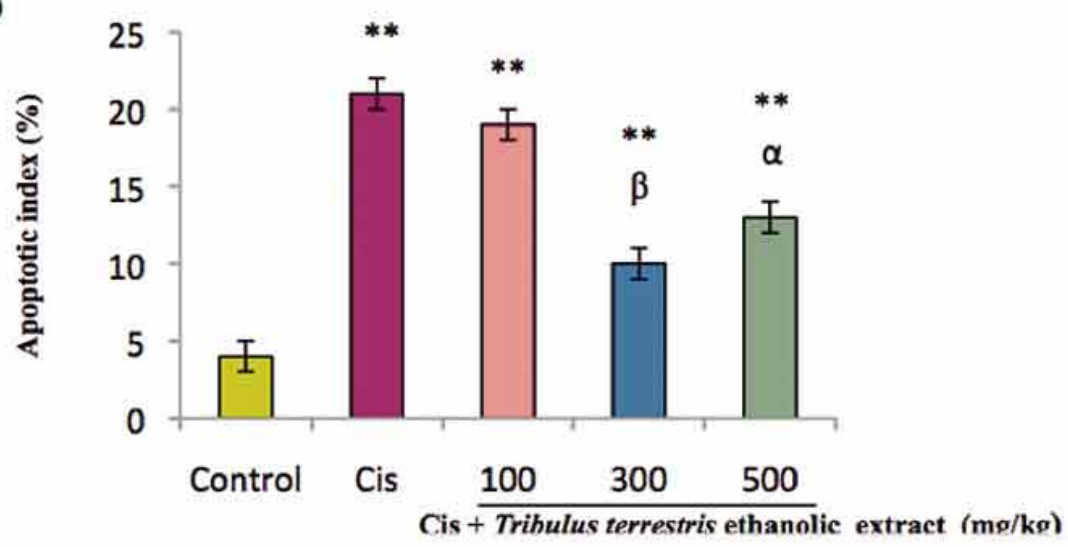

Fig. 1. The effect of toxic dose of cisplatin $(5.5 \mathrm{mg} / \mathrm{kg})$ and different doses of $T$. terrestris on A) body weights (left bar of the pairs is initial weights and the right bar is end weights), B) testis weight, C) diameter of seminiferous tubules, D) Apoptotic index. *= The mean difference is significant at the 0.001 level in comparison to the control group. $* *=$ The mean difference is significant at the 0.01 level, $a=P<0.05$ in comparison to the cisplatin group $(5.5 \mathrm{mg} / \mathrm{kg} / \mathrm{day}) . \mathrm{b}=$ $\mathrm{P}<0.01$ in comparison to the cisplatin group $(5.5 \mathrm{mg} / \mathrm{kg} /$ day $)$, $\mathrm{y}=\mathrm{P}<0.001$ in comparison to the cisplatin group ( $5.5 \mathrm{mg} / \mathrm{kg} /$ day). 


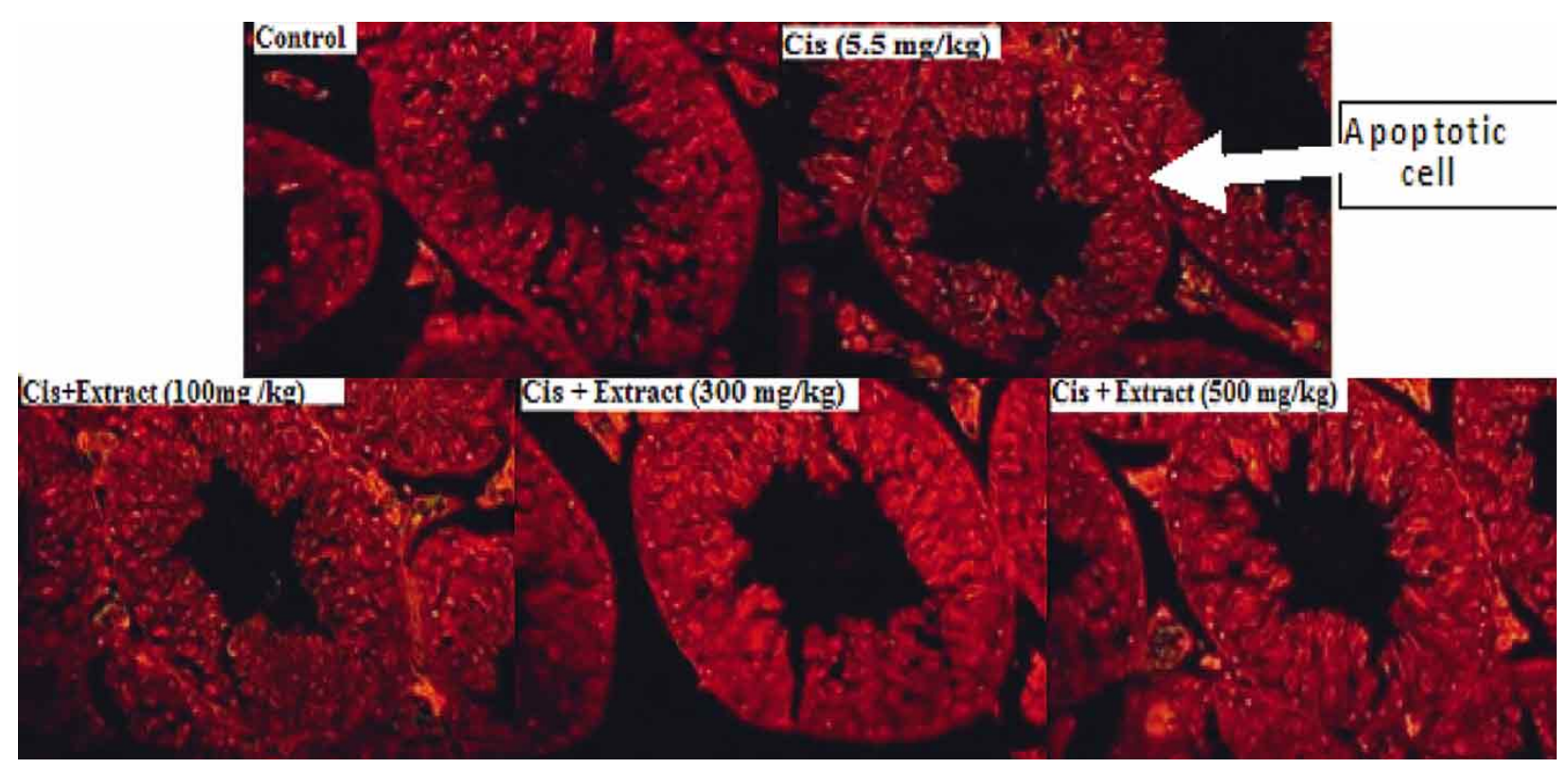

Fig. 2. The effect of toxic dose of cisplatin $(5.5 \mathrm{mg} / \mathrm{kg})$ and different doses of Tribulus terrestris on seminiferous tubules of balb/c mice (TUNEL staining, Arrow show TUNEL positive cells, X120).

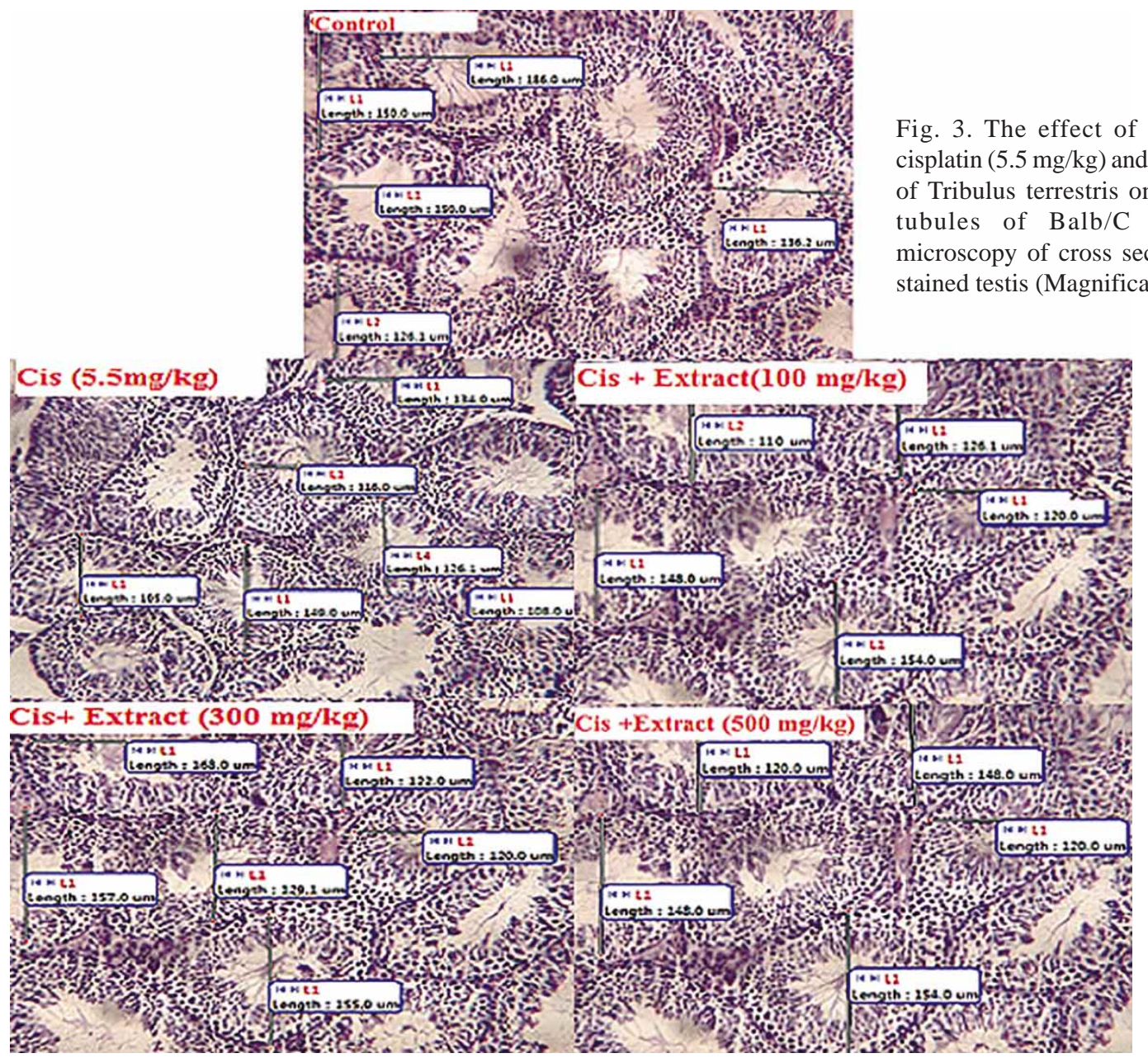




\section{DISCUSSION}

In the present study, protective effect of Tribulus terrestris hydroalcoholic extract on cisplatin-induced cytotoxicity in mice was evaluated. The results showed a significant declination in the weight of animals treated with cisplatin. These data supported other studies that indicated reductions in body weight could be attributable to toxic side effect of chemotherapeutic drugs and it suggests that $\mathrm{T}$. terristris reliefs the adverse effects of cisplatin (Yun et al., 2008). The present study also showed histological damage in testis of mice after 4 days of injection of one cytotoxic dose of cisplatin. The results obtained from the present study revealed a remarkable increase in body weight and reproductive organs weight, which were significantly higher than the controls after four days of treatment. Beside these therapies, herbal extracts have attracted the attention of many researchers for reducing the side effects of chemotherapeutic agents. This attenuation is based on the fact that free radicals that mediate reactions are responsible for a wide range of cisplatin induced side effects. Consequently, anti-oxidants have been shown to protect non-malignant cells and organs against damage by cisplatin (Atessahin et al., 2006).

This increase was possibly due to that treatment which affected the metabolic pathway towards hypoglycemic condition resulted in stimulation of growth hormone $(\mathrm{GH})$ secretion from anterior pituitary gland that encourages secretion of insulin like growth factors "IGF-I and II" (Ganong, 2005). This hormone is necessary to stimulate skeletal muscle growth, regulate lipolysis and promote cellular uptake of amino acids (Counchman \& Hammond, 1999).

This result is in agreement with other researchers who reported a significant increase in body weight of female mice (Abid, 2010), and male mice treated with TT extract. Insulin like growth factors I and II play important role in increasing protein synthesis and decreasing protein catabolism (Tawfiq, 2007).

The other possibility is that this increment may be due to the presence of some substance (s) in the extract that stimulates the regulation of fats and carbohydrates metabolism. It has been reported that TT may be a good appetizer and digestion promoter (Chopra et al., 1986).

In the present study, apoptotic DNA fragmentation was determined in testis using the TUNEL technique. A single dose of cisplatin caused apoptosis in testes (germ cells and sustentocytes). The high rate of apoptosis in the present study suggests that apoptosis is an important mechanism of toxicity of cisplatin. Chemotherapy leads to single and double DNA strand breaks, most often followed by cell death. Recent studies have shown the important role of apoptosis in the pathogenesis of cisplatin testicular (Arjumand et al., 2011; Kang et al., 2011)

Thus, together with other herbal extracts, TT reduces apoptosis of cisplatin by decreasing the number of apoptotic cells that can be considered as the antioxidant activity or diuretic effect of TT.

This increment may be caused by antioxidant activity of the extract or by some TT aqueous extract contents such as saponins (disgenin) and sterol (b-siosterol, stigma sterol), which contain phytoestrogen (Brinker, 1998).

On the other hand, the active chemical in TT is likely to be protodioscin (PTN (Gauthaman et al., 2002). The antioxidant activity of T. terrestriss could be attributed to its flavonoidal content (Harborne \& Williams, 2000). Flavonoids act as scavengers of various oxidizing species i.e. super oxide anion (O2-•), hydroxyl radical or peroxy radicals, they also act as quenchers of singlet oxygen (Das \& Pereira, 1997).

In conclusion, treatment of male mice with extract of TT showed obvious effects on the testis studied. The four days period of treatment seems to be more effective on both testis and apoptotic index.

ACKNOWLEDGEMENTS. The authors thank the Kermanshah University of Medical Science research fund for providing us with financial support on this work by grant no. 9205. There is no conflict of interest in this study.

KESHTMAND, Z.; GHANBARI, A.; KHAZAEI, M. \& RABZIA, A. Efecto protector del extracto hidroalcohólico de Tribulus terrestris contra la apoptosis inducida por cisplatino sobre los testículos en ratones. Int. J. Morphol., 33(1):279-284, 2015.

RESUMEN: El cisplatino es un medicamento anticancerígeno utilizado en tratamientos de quimioterapia. Uno de los efectos secundarios que limitan el uso del cisplatino es la disminución en la función de la glándula genital, provocando azoospermia y oligospermia. El Tribulus terrestris (TT) se ha utilizado como un afrodisíaco. El objetivo fue investigar el efecto protector del extracto hidroalcohólico de TT contra la apoptosis inducida por el cisplatino en los testículos de ratones. Ratones machos adultos $(n=30)$ fueron divididos en un grupo control y cuatro grupos experimentales ( $\mathrm{n}=6$ ). Al grupo control se le administró una solución salina, mientras que el primer grupo experimental recibió cisplatino $(5,5 \mathrm{mg} / \mathrm{kg})$ y los tres restantes recibieron cisplatino $(5,5 \mathrm{mg} / \mathrm{kg})$ con diferentes dosis del extracto hidroalcohólico de TT $(100,300$ y $500 \mathrm{mg} / \mathrm{kg} / \mathrm{ip})$, respectivamente. El día posterior a la última inyección, se realizaron análisis histopatológicos y morfométricos, junto al ensayo TUNEL, de los testículos de los ratones. Se registró el peso corporal y testicular de cada ratón, así como el diámetro de los túbulos seminíferos e índice de apoptosis. Los datos fueron analizados mediante ANOVA de una vía, seguida de la prueba de Tukey. El cisplatino provocó una reducción del peso corporal y testicular, y un aumento del índice de apoptosis, que fue 
significativo en comparación con el grupo control $(\mathrm{P}<0,001)$, mientras que en los grupos tratados con TT, el peso corporal y testicular, junto al diámetro de los túbulos seminíferos fueron significativamente mayores en comparación con el grupo tratado con cisplatino $(\mathrm{P}<0,001)$, sin embargo, el índice de apoptosis no mostró diferencias significativas. El estudio demuestra que el extracto de TT podría poseer un efecto protector de la apoptosis inducida por cisplatino sobre los testículos, así como en el diámetro de los túbulos seminíferos, lo que podría relacionarse con la presencia de componentes antioxidantes que actúan a través de diversos mecanismos, centrales y periféricos.

PALABRAS ClAVE: Cisplatino; Tribulus terrestris; Apoptosis; TUNEL.

\section{REFERENCES}

Abid, N. N. Effect of crude aqueous extract of Tribulus terrestris on some parameters of fertility in abino mice. M. Sc. Thesis. Baghdad, Institute of Embryo Researches and Infertility Treatment, Al-Nahrain University, 2010.

Abbas, A. M.; Ahmed, A. A. H. A. A.; Heba, H. I. A. M. \& Amir, H. A. Study the biological activities of Tribulus terrestris extracts. J. Biotechnol. Res. Cent., 4(1):55-60, 2010.

Arjumand, W.; Seth, A. \& Sultana, S. Rutin attenuates cisplatin induced renal inflammation and apoptosis by reducing NFkB, TNF-a and caspase-3 expression in wistar rats. Food Chem. Toxicol., 49(9):2013-21, 2011.

Atessahin, A.; Karahan, I.; Türk, G.; Gür, S.; Yilmaz, S. \& Ceribas, i, A. O. Protective role of lycopene on cisplatin-induced changes in sperm characteristics, testicular damage and oxidative stress in rats. Reprod. Toxicol., 21(1):42-7, 2006.

Bagnis, C.; Beaufils, H.; Jacquiaud, C.; Adabra, Y.; Jouanneau, C.; Le Nahour, G.; Jaudon, M. C.; Bourbouze, R.; Jacobs, C. \& Deray, G. Erythropoietin enhances recovery after cisplatin-induced acute renal failure in the rat. Nephrol. Dial. Transplant., 16(5):932-8, 2001.

Brinker, F. Herb contraindications and drug interactions. 2nd ed. Sandy (OR), Eclectic Medical Publications, 1998.

Brozovic, A.; Ambriovic-Ristov, A. \& Osmak, M. The relationship between cisplatin-induced reactive oxygen species, glutathione, and BCL-2 and resistance to cisplatin. Crit. Rev. Toxicol., 40(2):347-59, 2010.

Chehreie, S.; Sadri, S.; Khazaei, M.; Ghanbari, A.; Ayubian, M. \& Amiri, S. Prenatal water deprivation induces apoptosis in sexual dimorphic nucleus of the brain of male new born Sprague-Dawley rats. Int. J. Morphol., 29(2):496-500, 2011.

Chirino, Y. I. \& Pedraza-Chaverri, J. Role of oxidative and nitrosative stress in cisplatin-induced nephrotoxicity. Exp. Toxicol. Pathol., 61(3):223-42, 2009 .

Chopra, R. N.; Nayar, S. L. \& Chopra, I. C. Glossary of Indian medicinal plants (Including the supplement). New Delhi, Council Scientific Industrial Research, 1986.

Couchman, G. M. \& Hammond, C. B. Phyè "flogy of reproduction. In: Danforth, D. N. \& Scott, J. R. Danforth's Obstetrics and Gynecology. 8th ed. New York, Lippincott, Williams \& Wilkins, 1999.
Das, N. P. \& Pereira, T. A. Effects of flavonoids on thermal autoxidation of palm oil: Structure-activity relationships. J. Am. Oil Chem. Soc., 67(5):255-8, 1997.

Frezza, M.; Hindo, S.; Chen, D.; Davenport, A.; Schmitt, S.; Tomco, D. \& Dou, Q. P. Novel metals and metal complexes as platforms for cancer therapy. Curr. Pharm. Des., 16(16):1813-25, 2010.

Gauthaman, K. \& Ganesan, A. P. The hormonal effects of Tribulus terrestris and its role in the management of male erectile dysfunction--an evaluation using primates, rabbit and rat. Phytomedicine, 15(1-2):44-54, 2008.

Gauthaman, K.; Adaikan, P. G. \& Prasad, R. N. Aphrodisiac properties of Tribulus Terrestris extract (Protodioscin) in normal and castrated rats. Life Sci., 71(12):1385-96, 2002.

Ganong, W. F. The gonads: development and function of the reproductive system. In: Ganong, W. F. (Ed.). Review of Medical Physiology. 22nd ed. New York, McGraw- Hill, 2005.

Harborne, J. B. \& Williams, C. A. Advances in flavonoid research since 1992. Phytochemistry, 55(6):481-504, 2000

Karimi, J. H.; Malekzadeh, S. S. \& Hoshmand, F. The effect of the Tribulus terrestris extract on spermatogenesis in the rat. J. Jahrom Univ. Med. Sci., 9(4):7-11, 2012

Kang, K. P.; Park, S. K.; Kim, D. H.; Sung, M. J.; Jung ,Y. J.; Lee, A. S.; Ramkumar, K. M.; Lee, S.; Park, M. H.; Roh, S. G. \& Kim, W. Luteolin ameliorates cisplatin-induced acute kidney injury in mice by regulation of p53-dependent renal tubular apoptosis. Nephrol. Dial. Transplant., 26(3):814-22, 2011

Khazaei, M. \& Salehi, H. Protective effect of Falcaria vulgaris extract on ethanol- induced gastric ulcer in rat. Iran. J. Pharmacol. Ther.,5(1):43-6, 2006.

Lirdi, L. C.; Stumpp, T.; Sasso-Cerri, E. \& Miraglia, S. M. Amifostine protective effect on cisplatin-treated rat testis. Anat. Rec. (Hoboken), 291(7):797808, 2008.

Orazizadeh, M.; Khorsandi, L. S. \& Hashemitabar, M. Toxic effects of dexamethasone on mouse testicular germ cells. Andrologia, 42(4):24753,2010 .

Tawfiq, L. J. Effect of Tribulus terrestris extract on reproduction in mature male mice. M. Sc. Thesis. Baghdad, Institute of Embryo Researches and Infertility Treatment, Al-Nahrain University, 2007.

Yun, J. W.; Shin, E. S.; Cho, S. Y.; Kim, S. H.; Kim, C. W.; Lee, T. R. \& Kim, B. H. The effects of BADGE and caffeine on the time-course response of adiponectin and lipid oxidative enzymes in high fat diet-fed C57BL/6J mice: correlation with reduced adiposity and steatosis. Exp. Anim., 57(5):461-9, 2008

Correspondence to:

Ali Ghanbari, Ph.D

Fertility and Infertility Research Center

Kermanshah University of Medical Sciences

Kermanshah

IRAN

Email: aghanbari@kums.ac.ir

Received: 29-05-2014 Accepted: 14-01-2015 